\title{
Recent Advances in Fish Biotechnology: A Review
}

\author{
Renu Singh ${ }^{1}$ and Babita Rani $^{2 *}$ \\ ${ }^{1}$ Department of Biotechnology and Molecular Biology and ${ }^{2}$ Department of Biochemistry, \\ Chaudhary Charan Singh Haryana Agricultural University (CCS HAU), \\ Hisar, Haryana-125004, India \\ *Corresponding author
}

\section{Keywords}

Biotechnology,

Breeding, Fish,

Molecular

techniques

\section{Article Info}

Accepted:

18 May 2020

Available Online:

10 June 2020

\section{A B S T R A C T}

The role of aquaculture in increasing fish production is well recognized today. The contribution of aquaculture to global food production and security has been widely acknowledged since the start of the 21 st century. Global aquaculture production has increased continuously over the last five decades, and particularly in India, aquaculture has become one of the fastest growing and most efficient agri-sector. Biotechnology can currently be considered of importance in aquaculture. The increase in the production of aquatic organisms over the last two decades through the use of biotechnology indicates that in a few generations biotechnology may overtake conventional techniques, at least for the commercially more valuable species. At present, the most commonly used methods in fish biotechnology are the use of synthetic hormones in fish breeding, production of monosex, uniparental and polyploid individuals which can be used to produce triploid, tetraploid, haploid, gynogenetic and androgenetic fish, molecular biology and transgenesis, biotechnology in aquaculture nutrition and health management, gene banking are chromosome manipulation and hormonal treatments.

\section{Introduction}

According to United Nations Food and Agriculture Organization (FAO) (2014), "Global fish production continues to outpace world population growth, and aquaculture remains one of the fastest-growing food producing sectors it appears unlikely that the increasing demand can be met through increased natural harvest. There is international recognition that many of natural ocean and freshwater fisheries are being harvested to their limit. Aquaculture could help to meet increasing demand, and biotechnology can make a great contribution to improve aquaculture yields. If responsibly developed and practiced, aquaculture can generate lasting benefits for global food security and economic growth" (Food and Agriculture). The future of fish and aquaculture potentials has been the subject of extensive discussion (Naylor et al., 2000, Pauly et al., 2002). 
Advances in biotechnology over the past several decades have provided the tools necessary for artificial manipulation of genes and chromosomes in living organisms. The creation of transgenic fish and shellfish is a topic of great interest in aquaculture research due to the potential improvements in production that this technology can offer (Zbikowska, 2003; Dunham, 2004). Major areas of transgenic research in fish include use of growth hormones (GHs) to increase growth and feed conversion efficiency; use of antifreeze proteins (AFPs) for enhanced cold tolerance and freeze resistance; use of antimicrobial peptides for increased disease resistance; use of metabolic genes to promote low-cost, land based diets; and genetic methods for inducing sterility. In addition to transgenic research, advances in chromosome manipulation (polyploidy) also show potential for improving production in the aquaculture industry, particularly in the case of shellfish. Uses of polyploidy in aquaculture can resultin sterility, along with enhanced growth and survival rates and increased quality of final products. The development of improved fish seed stocks that can contribute to increased fish production is seen as one of the key solutions to meeting the future food demands of the growing world population (Hammed). Biotechnology has opened a new window for development of genetic resources in aquaculture. Genetic technologies can be utilized in aquaculture for a variety of reasons, not just to improve production but also marketability, cultivability and the conservation of natural resources (Moses et al., 2005).

\section{Biotechnology techniques in fish breeding}

Since the early 1980s, research in aquaculture and fisheries genetic biotechnology has steadily grown, and now research in this area is extremely active. The main vision of aquaculture biotechnology is to achieve improvements of aquaculture stock, preservation of genetic resources, disease diagnosis, and control of microbial/microalgal genetic engineering (Nwokwa, 2012). In broad terms, biotechnology can be defined as any technological application that uses biological systems, living organisms or derivatives thereof, to make or modify products or processes for specific use (Wikipedia, 2018). Biotechnology has the potential to enhance reproduction and the early developmental success of culture organism.

\section{Chromosome manipulation}

Chromosome sex manipulation techniques to induce polyploidy (triploidy and tetraploidy) and uniparental chromosome inheritance (gynogenesis and androgenesis) have been applied extensively in cultured fish species (Pandian and Koteeswaran, 1998; Lakra and Das, 1998). These techniques are important in the improvement of fish breeding as they provide a rapid approach for gonadal sterilization, sex control, improvement of hybrid viability and clonation.

\section{Triploidy}

Induced triploidy is widely accepted as the most effective method for producing sterile fish for aquaculture and fisheries management (Lakran and Ayyappan, 2003). Inducing triploidy is the only practical means in which to sterilize large numbers of fish without using of potentially harmful chemicals or radiation (Benfey, 1989). It is through the triploidization technique that sterilization can be achieved by administration of an environment shock shortly post fertilization (Kizak et al., 2013). Culture of triploid fish can be advantageous for several reasons. The potential of increased growth, increased carcass yield, increased survival and increased flesh quality are the main culture 
advantages. Triploids would reach a larger size than diploids because of their larger cell size (Dunham, 2004). (Taniguchi et al., 1986)reported increased growth rate in triploid fish compared to their normal diploid siblings. This increased growth rate can be a result of lack of sexual development since the growth rate of fish slows as they approach sexual maturity or increased cell size. Therefore, degradations due to sexual maturation are overcome by triploidy technique (Piferrer et al., 2009).

Methods of triploidy induction include: temperature shock (hot or cold), hydrostatic pressure shock, chemicals (such as colchicine, cytochalasin-B or nitrous oxide), and the crossing of tetraploids with diploids.

\section{Tetraploidy}

Tetraploids have a balanced set of chromosomes, which can result in viability and fertility. Tetraploidy in fish is commonly produced by disrupting the first cleavage with thermal or hydrostatic pressure shocks in eggs fertilized with normal sperm. Viable tetraploids have been produced by these methods in a number of fish species (Pandian et al., 1998). Tetraploid breeding lines are of potential benefit to aquaculture by providing a convenient way to produce large numbers of sterile triploid fish through simple crosses between tetraploids and diploids (Guo et al., 1996). The success of treatments to induce polyploidy depends on the time of initiation of the shock, the magnitude of the shock, duration of the shock, genetics and quality of the gametes

\section{Sex control}

The use of sex control techniques to influence characteristics of economically desirable teleost species is becoming an important management tool to increase aquaculture production. Techniques that allow production of monosex population by sex manipulation are potentially useful in species where one sex is more useful than the other. There are basically two ways of sex manipulation i.e. hormonal and genetic.

\section{Hormonal sex reversal}

The production of single sex groups of fish can be accomplished by manipulation of the developing gametes and embryo (FAO, 2014). The principle behind this method lies on the fact that at the stage when the fish larvae are said to be sexually undifferentiated (right after hatching up to about 2 weeks or up to the swim-up stage), the extent of the androgen (male hormone) and the oestrogen (female hormone) pre-sent in a fish is equal (Fuentes et al., 2013). The artificial elevation of the appropriate sex hormone is sufficient to overcome the natural hormone or gene product during the period of sexual differentiation and to dictate the sex of the individual (Dunham, 2004).

\section{Hybridization}

Increased heterozygosity from hybridization has resulted in improved growth and other desirable characters such as developmental compatibility, food conversion efficiency, and oxygen metabolism in a variety of species (Danzmann et al., 1985).

Hybridization attempts to produce fish that combines valuables traits from more than one species or high heterosis (hybrid vigour) (Aluko, 1993). Hybridization is aimed to evolve a hybrid or strain of superior quality than the parent species. In Nigeria, Clarias gariepinus and Heterobranchus bidorsalis have been crossed to produce a sterile hybrid which possessed the hardiness of Clarias and the fast growth of Heterobranchus. 


\section{Induced breeding}

Artificial propagation methods constitute a major practicable means of providing enough quality seed for rearing in confined enclosure such a fish ponds, reservoirs and lakes (Charo and Oirere, 2000). Fish culture today is hardly possible without the artificial propagation of fish seeds of preferred cultivable fish species. Apart from being able to obtain quality seed, the artificial propagation technique can also be used to develop strains superior to their ancestors by the methods of selective breeding and hybridization (Akankali et al., 2011).

The induced breeding of fish is now successfully achieved by the development of Gonadotropin releasing hormone $(\mathrm{GnRH})$ technology (Lakran and Ayyappan, 2003). $\mathrm{GnRH}$ is the key regulator and central initiator of reproductive cascade in all vertebrates (Bhattacharya et al., 2002). It is a decapeptide with the ability to induce pituitary release of luteinising hormone $(\mathrm{LH})$ and follicle stimulating hormone (FSH) (Schally, 1973).

\section{Molecular markers}

Recent advances in molecular biology have provided unlimited number of genetic markers which have multiple application in aquaculture and fisheries (Lakra, 2001). Molecular genetics approaches began to be used in fisheries in the 1950s. Their use in aquaculture and fisheries has increased dramatically over the past few years. The genetic identification of aquaculture stocks is a fundamental requirement in any culture programme. Mitochondrial DNA has provided a wealth of genetic markers to answer questions on the phylogeny, evolution and population structure of fishes. Genetic markers can be used to identify individuals and family groups so that they can be reared together thus simplifying experimental designs. One very powerful application of the new DNA based technologies is to identify marker loci which are associated with nuclear loci that control economically important traits (quantitative trait loci or QTLs). Once such markers have been identified they can be used in selection programmes. An approach towards his marker assisted selection (MAS) in fish has been made in rainbow trout by Herbinger et al., (1995).

\section{Uniparental fish production}

The production of fish with uniparental genetic material is also becoming common in biotechnology. This system operates on the same principle as monosex culture where the traits of one parent are preferred over the other parent's.

\section{Androgenesis}

Androgenesis is the process by which a progeny is produced by the male parent with no genetic contribution from female. Induction of androgenesis can produce allmale population in fish which would have commercial application in aquaculture. It involves two steps: the first treatment is the deactivation of the female genome by UV or gamma rays. Egg activation with untreated spermatozoa then requires diploidization of the haploid zygote by some form of shock to interrupt the first mitotic division (Shelton, 2000). Otherwise, a diploid sperm - the gonad product of a tetraploid male - is needed to fertilise the irradiated egg and produce diploid embryos without further treatment (Beaumont, 2010).

\section{Gynogenesis}

Gynogenesis is the process of animal development with exclusive maternal inheritance. Gynogenesis involves the 
parthenogenetic development of an egg or the stimulation of an egg by a genetically inactive spermatozoon. All-female inheritance is accomplished by activating cell division with irradiated sperm and then restoring diploidy to the developing zygote (Aluko, 1993). Retention of the polar body is accomplished with temperature shocks or pressure treatments.

\section{Transgenesis}

Transgenesis or transgenics may be defined as the introduction of exogenous gene/DNA into host genome resulting in its stable maintenance, transmission and expression. The technology offers an excellent opportunity for modifying or improving the genetic traits of commercially important fishes, mollusks and crustaceans for aquaculture. The idea of producing transgenic animals became popular when Palmiter et al., (1982) first produced transgenic mouse by introducing metallothione- in human growth hormone fusion gene (mT-hGH) into mouse egg, resulting in dramatic increase in growth. This triggered a series of attempts on gene transfer in economically important animals including fish.

A foreign gene can be transferred into fish in vivo by introducing DNA either into embryos or directly into somatic tissues of adults (Hew, 1995). Direct delivery of DNA into fish tissues is a simple approach, providing fast results and eliminating the need for screening transgenic individuals and selecting germ line carriers. Gene transfer and expression following intramuscular direct injection of foreign DNA into skeletal muscles of fish has been achieved (El-Zaeem, 2004).

Although significant progress has been made in several laboratories around the world, there are numerous problems to be resolved before the successful commercialization of the transgenic brood stock for aquaculture. To realize the full potential of the transgenic fish technology in aquaculture, several important scientific break-through are required. These include i) more efficient technologies for mass gene transfer ii) targeted gene transfer technologies such as embryonic stem cell gene transfer iii) suitable promoters to direct the expression of transgenes at optimal levels during the desired developmental stages iv) identified genes of desirable traits for aquaculture and other applications v) information on the physiological, nutritional, immunological and environmental factors that maximize the performance of the transgenics and vi) safety and environmental impacts of transgenic fish.

\section{Cryopreservation of gametes or gene banking}

Cryopreservation is a technique, which involves long term preservation and storage of biological material at very low temperature, usually at $-19{ }^{\circ} \mathrm{C}$, the temperature of liquid nitrogen. It is based on the principle that very low temperatures tranquilize or immobilize the physiological and biochemical activities of cells, thereby, making it possible to keep them viable for very long period. Cryopreservation overcomes the problem of males maturing before females, allows selective breeding and stock improvement and enables the conservation of genomes (Harvey, 1996). One of the emerging requirements for undertaking gene banking of aquatic resources is the need to build a genetic base collection that can be used by breeders for evolving new strains. Aquatic gene banks however, suffer from the fact that at present it is possible to cryopreserve only the male gametes of finfishes and there in no viable technique for finfish eggs and embryos. 
Based on the above discussions, it can be concluded that genetic technology is rapidly being applied in aquaculture. Hormonal treatments that regulate the action of genes and modify the sex of offspring are now widely used in fish culture programs. Chromosome manipulation, resulting in sterile polyploid individuals or monosex inbred lines, constitutes an important tool. DNA markers are being used to study stock identification and population differences, in gene mapping studies, and potentially as aids to selective breeding programs. Gene transfer work in many species of fish, stimulated by the possibility of producing rapidly-growing individuals through the introduction of foreign growth hormone genes, has produced modified fish in numerous laboratories around the world. Thus, the production of cells containing new gene arrangements some of them introduced by chromosome manipulation or by gene transfer, could be undertaken in tissue culture to give new combinations of genetic material. Furthermore, the organization of gene banks based on collections of frozen sperm and cells or on purified DNA molecules, obtained from different fish species, should be considered and could play an important role in the future.

\section{References}

Akankali, J. K., Seiyaboh, E. I., and Abowie, J. F. N. (2011). Fish Hatchery Management in Nigeria. Advance Journal of Food Science and Technology, 3 (2), 144-154

Aluko, P. O. (1993). Techniques of Producing Monosex or Sterile Population of Fish for Aquaculture - A Review of Selected Literature. Proceedings of the $10^{\text {th }}$ Annual Conference of Fisheries Society of Nigeria, 163-172

Beaumont, A., Boudry, P., and Hoare, K. (2010). Biotechnology and Genetics in Fisheries and Aquaculture - 2nd
Edition. Wiley-Blackwell Publishing, 202

Benfey, T. J. (1989). A Bibliography of Triploid Fish, 1943 to 1988. Canadian Technical Report Fisheries and Aquatic Science, Department of Fisheries and Oceans, West Vancouver, British Columbia, Canada, 37

Bhattacharya, S., Dasgupta, S., Datta, M., and Basu, D. (2002). Biotechnology Input in Fish Breeding. Indian Journal of Biotechnology, 1, 29-38

Charo, H., and Oirere, W. (2000). Riverbased Artificial Propagation of the African Catfish (Clarias gariepinus): An Option for the Small Fish Farmer. NAGA-The ICLARM Q, 2 (1), 14-16

Danzmann, R. G., Ferguson, M. M., and Allendorf, F. W. (1985). Does Enzyme Heterozygosity Influence Developmental Rate in Rainbow Trout? Heredity, 56, 417-425

Dunham, R.A. (2004). Aquaculture and fisheries biotechnology: genetic approaches. Cambridge, Mass.: CABI Publishing, 372

El-Zaeem, S. Y., and Aseem, S. S. (2004). Application of Biotechnology in Fish Breeding: Production of Highly Immune Genetically Modified Nile Tilapia, Orechromis niloticus, with Accelerated Growth by Direct Injection of Shark DNA into Skeletal Muscles. Egyptian Journal of Aquatic Biology and Fisheries, 8 (3), 67-92

Food and Agriculture Organization (2014). Genetic Biotechnologies. Fisheries and Aquaculture Department of the Food and Agriculture Organization of the United Nations. www.fao.org/fishery/

Fuentes-Silva, C., Soto-Zarazua, G. M., Torres-Pacheco, I., and Flores-Rangel, A. (2013). Male Tilapia Production Techniques: A Mini-Review. African 
Journal of Biotechnology, 12 (36), 5496-5502

Guo, X., G. A. DeBrosse., and S. K. Allen, Jr., (1996). All triploid Pacific oysters (Crassostreagigas thunberg) produced by mating tetraploids and diploids. Aquaculture, 142: 149-161

Harvey, B. (1996). Salmon gene banking: a conservation opportunity. Publ. World. Fisheries Trust, Canada, 83

Herbinger, C. M., R. W. Doyle., E. R. Pitman., D. Paquet., K. A. Mesa., D. B. Morris., J. M. Wright., and D. Cook. (1995). DNA fingerprint based analysis of paternal and maternal effects on offspring growth and survival in communally reared rainbow trout. Aquaculture 137: 245256

Hew, C. L., G. L. Fletcher., and Davies, P. L. (1995). Transgenic Salmon: Tailoring the Genome for Food Production. Journal of Fish Biology, 47, 1-9

Kizak, V., Guner, Y., Turel, M., and Kayim, M. (2013). Comparison of Growth Performance, Gonadal Structure and Erythrocyte Size in Triploid and Diploid Brown Trout (Salmo trutta). Turkish Journal of Fisheries and Aquatic Science, 13, 571-580

Lakra, W. S. (2001). Genetics and Molecular Biology in Aquaculture - Review. Asian-Aust. J. Anim. Sci. 14(6), 894898

Lakra, W. S., and P. Das. (1998). Genetic engineering in aquaculture. Indian. $\mathbf{J}$. Anim. Sci., 68 (8), 873-879

Lakran, W. S., and Ayyappan, S. (2003). Recent Advances in Biotechnology Applications to Aquaculture. AsianAustralian Journal of Animal Science, 16 (3), 455-462.

Moses, Y., S. O. Olufeagba., and Raphael, A. Z. (2005). Intra-specific hybridization in two strains of Clarias gariepinus (Limnaeus, 1758). In: M. I. Nguru, C.
U. Iroegion and V. C. Ejere (eds). Genetics Society of Nigeria 30th Annual National Conference, Nsukka. 5th-8th September, 153-158

Naylor, R.L., Goldburg, R.J., Primavera, J. H., Kautsky, N., Beveridge, M.C., Clay, J., Folke, C., Lubchenco, J., Mooney, H., and Troell, M. (2000), Effect of aquaculture on world Fish supplies. Nature, 405, 1017-1024

Nwokwa, M. C. (2012). The Review of Recent Advances in Fish Genetics and Biotechnology. Continental Journal of Fisheries and Aquatic Science, 6 (1), 9-18

Palmiter, R. D., R. L. Brinster., R. E. Hammer., M. E. Trumbauer and M. G. Rosenfeld. (1982). Dramatic growth of mice that develop from eggs microinjected with metallothionein growth hormone fusion genes. Nature 30, 611-615

Pandian, T. J., and R. Koteeswaran. (1998). Ploidy induction and sex control in fish. Hydrobiologia 384, 167-243

Pauly, D., Christensen, V., Guénette, S., Pitcher, T.J., Sumaila, U.R., Walters, C.J., Watson, R., and Zeller, D. Towards sustainability in world fisheries. Nature, (2002), 418, 689695

Piferrer, F., Beaumont, A., Falguière, J. C., Flajshans, M., Haffray, P., and Colombo, L. (2009). Polyploid Fish and Shellfish: Production, Biology and Applications to Aquaculture for Performance Improvement and Genetic Containment. Aquaculture, 293, 125-156

Schally, A., Arimura, A., and Kastin, A. J. (1973). Hypothalamic Regulatory Hormones. Science, 179, 341-350

Shelton, W. L. (2000). Methods for Androgenesis Techniques Applicable to Tilapia. In: K. McElwee, D. Burke, M. Niles, X. Cummings, and H. Egna 
(Editors), Seventeenth Annual Technical Report. Pond Dynamics/Aquaculture CRSP, Oregon State University, Corvallis, Oregon, 51-55

Taniguchi, N., Kijima, A., Tamura, T., Takegami, K., and Yamasaki, I. (1986). Colour, growth and maturation in ploidy-manipulated fancy carp. Aquaculture, 57, 321-328

Wikipedia (2014). Biotechnology (Accessed June, 2014) www.wikipedia.org

Zbikowska, H.M. (2003). Fish can be firstadvances in fish transgenes is for commercial applications. Transgenic Res 12 (4), 379-89.

\section{How to cite this article:}

Renu Singh and Babita Rani. 2020. Recent Advances in Fish Biotechnology: A Review. Int.J.Curr.Microbiol.App.Sci. 9(06): 1667-1674. doi: https://doi.org/10.20546/ijcmas.2020.906.206 